\title{
Region and Field Level Distributions of Aster Yellows Phytoplasma in Small Grain Crops
}

C. R. Hollingsworth and L. M. Atkinson, Northwest Research and Outreach Center, Department of Plant Pathology, University of Minnesota, Crookston 56716; D. A. Samac, United States Department of Agriculture-Agricultural Research Service, Plant Science Research, Department of Plant Pathology, University of Minnesota, St. Paul 55108; J. E. Larsen, Department of Plant Pathology, University of Minnesota, St. Paul 55108; C. D. Motteberg, Northwest Research and Outreach Center, Department of Plant Pathology, University of Minnesota, Crookston; M. D. Abrahamson, Minnesota Department of Agriculture, St. Paul 55155; P. Glogoza, University of Minnesota Extension, Regional Center, Moorhead 56560; and I. V. MacRae, Northwest Research and Outreach Center, Department of Entomology, University of Minnesota, Crookston

\begin{abstract}
Hollingsworth, C. R., Atkinson, L. M., Samac, D. A., Larsen, J. E., Motteberg, C. D., Abrahamson, M. D., Glogoza, P., and MacRae, I. V. 2008. Region and field level distributions of aster yellows phytoplasma in small grain crops. Plant Dis. 92:623-630.

Aster yellows (AY), a disease of small grain crops caused by aster yellows phytoplasma (AYp), produces disease symptoms similar to barley yellow dwarf (BYD). From 2003 to 2005, small grain production fields in Minnesota and North Dakota were surveyed to determine the incidences of AY and BYD. In-field spatial patterns of AY-infected plants also were investigated. Plants collected along a five-point transect line were tested for AYp using nested polymerase chain reaction (PCR) and quantitative real-time PCR assays, and extracted plant sap was tested for serotypes PAV and RPV of Barley yellow dwarf virus (BYDV) using enzyme-linked immunosorbent assays. During 2003, 2004, and 2005, AYp was detected in plants from 49, 15, and 7\% of tested fields, respectively, whereas BYDV was found in plants from 2, 0 , and $5 \%$ of fields, respectively. Average amplicon count number indicated an in-field spatial trend for greater incidence of AYp and increased populations of AYp in plants located near field edges, with comparably low copy numbers at transect point locations toward the direction of field center. AY is likely a common but largely undetected disease on small grain crops in the Upper Midwest.
\end{abstract}

Additional keywords: Avena sativa, Hordeum vulgare, oat, Triticum aestivum, wheat

Diseases caused by phytoplasmas, previously termed mycoplasma-like organisms (MLOs), occur in a wide range of plant species. Aster yellows (AY) disease is reported from at least 350 mono- and dicotyledonous, cultivated and wild plant species worldwide (22,35). Previously thought to be of viral origin, the classification of phytoplasmas is taxonomically in flux, with some subgroups being designated as Candidatus spp. in a provisional classification system $(10,11,18,22)$. As a rule, phytoplasmas (i) are not culturable on artificial media, (ii) are pleomorphic due to a flexible cell membrane, (iii) have a small genome compared with bacteria having cell walls, (iv) have a low guanine and cytosine content, (v) are heat treatment sensitive, and (vi) respond to plant uptake of tetracycline antibiotics through symp-

Corresponding author: C. R. Hollingsworth

E-mail: holli030@umn.edu

Accepted for publication 19 November 2007.

doi:10.1094/PDIS-92-4-0623

(C) 2008 The American Phytopathological Society tom remission during treatment $(13,16,17$, $19,20,22,27,38,42,43)$.

Aster yellows phytoplasma (AYp) is classified within the DNA-delineated group, or subclade, of 16SrI $(22,24)$. Phytoplasmas are introduced into the phloem tissues of a healthy host through infected leafhopper feeding. The AYp is vectored by at least 24 leafhopper species, although the primary insect vector is the aster, or six-spotted, leafhopper, Macrosteles quadrilineatus Forbes, formerly $M$. fascifrons (Stål) $(5,10,14)$.

The Red River Valley of Minnesota and North Dakota is an important production area of hard red spring wheat (Triticum aestivum L.) and spring barley (Hordeum vulgare L.). Small grain seedlings are a preferred early season food source and breeding environment for aster leafhopper populations arriving from the southern United States $(34,35,40,41)$. A subset of immigrating leafhoppers is routinely AYp infective each spring, and early infection of a susceptible host increases disease severity (5). Vegetable and field crop losses caused by AY have been reported in the Upper Midwest and southern Canadian provinces $(33,35,37,39)$.
During 2002, AYp was confirmed in symptomatic spring wheat plants growing in a University of Minnesota Extension Service varietal trial demonstration located in northwest Minnesota, near Strathcona. Plants exhibited disease symptoms ranging from chlorotic leaf blotches to complete plant collapse. Many plants exhibited redto-purplish blotches on leaves that turned necrotic with time. Symptoms were indistinguishable from those caused by Barley yellow dwarf virus (BYDV). Banttari (4) noted the same phenomenon from a barley field experiment nearly 40 years earlier, when barley plants inoculated with AYp or BYDV produced disease symptoms that were indistinguishable. He concluded that diagnoses of causal organisms could not be made without transmission tests in areas where both diseases were prevalent. During 2001, symptoms of barley yellow dwarf (BYD) such as leaf chlorosis and leaves showing red-to-purplish blotches or stripes were reported near Fargo, ND early in the growing season. At that time, aphid populations were nil to low, while aster leafhopper populations were abundant and reported in west-central Minnesota $(29,31)$. Observations based solely on field symptoms by agricultural professionals and producers commonly result in diagnoses of BYD. These diagnoses, in the absence of laboratory testing, are in question because BYD is reported during years when populations of its aphid vector are low. The objectives of this study were to (i) analyze and compare multiyear distribution of AYp and BYDV infestations in the RRV and (ii) determine whether naturally AYp-infested plants occur in patterns within commercial production fields.

\section{MATERIALS AND METHODS}

Plant collection. During 2003, 2004, and 2005, small grain plant samples were collected from commercial production fields located at least $16 \mathrm{~km}$ apart along state-, county-, and township-maintained roadways, primarily in west-central and northwest Minnesota. A few samples also were collected from northeast North Dakota. Plant collections began in May or 
June and continued through July or August.

In all, 25 plants were collected from each surveyed field along a W-shaped transect line. Five plants at each of five points on the figure were selected arbitrarily from fields and removed using a garden trowel or small shovel. Collection point no. 1 was situated near the field edge at entry and each succeeding point on the transect line thereafter was approximately $15 \mathrm{~m}$ distant from the preceding point in the direction of field center (point 1 at $0 \mathrm{~m}$, point 2 at $15 \mathrm{~m}$ from point 1 , point 3 at 30 $\mathrm{m}$ from point 1 , point 4 at $45 \mathrm{~m}$ from point 1 , and point 5 at $60 \mathrm{~m}$ from point 1 ).

During 2003, 271 fields were surveyed in 18 Minnesota and 2 North Dakota counties from 21 May to 1 August (Table 1). Twenty-five plants were bagged together and the collection date, plant species, and crop growth stage recorded. Geographic coordinates of each field were recorded using a hand-held global positioning system (GPS). Samples were stored on ice during the survey and later were transferred to cold storage $\left(-20^{\circ} \mathrm{C}\right)$.

During 2004, 218 fields were surveyed as described above. An additional 132 fields were surveyed using a second plant collection protocol that preserved transect point location data from which AYp infield patterns could be assessed. Five plants collected from each transect point location were placed in a plastic bag and the collection date, plant species, crop growth stage, and transect point GPS coordinates were recorded. As before, plants initially were stored on ice and later trans- ferred to cold storage. In all, 350 fields were surveyed in 17 Minnesota counties between 4 June and 13 July (Table 1).

During 2005, the second protocol was used for all plant collections. Plants were collected from a total of 265 fields in one North Dakota county and 20 Minnesota counties between 31 May and 29 July (Table 1).

Survey locations were analyzed by year for area aggregation of plants detected with AYp. Using the geographic coordinates and considering each surveyed field as a location point, GS+ V.5.1 (Gamma Design Software, Plainwell, MI) was used to calculate Moran's indices. Moran's indices spatial analysis is a conventional measure of autocorrelation wherein resultant values close to 1 indicate sample aggregation, values close to 0 represent random distribution, and values close to -1 indicate an even distribution (32).

DNA extraction. Populations of phytoplasma are limited to phloem transport cells within infected plants. Reliably detecting a systemic, low-titer phloem pathogen from plant tissue is challenging when the pathogen is not evenly distributed throughout the plant $(12,17)$.

During 2003, total DNA was extracted from upper nodes, lower nodes, upper leaves, lower leaves, roots, and stems (when nodes were not yet present) of collected plants. Each sample was extracted and analyzed separately. During 2004 and 2005, a total of four nodes approximately $0.6 \mathrm{~cm}$ in length were excised from upper and lower culm positions, and four leaf sections about 1.3 to $2.5 \mathrm{~cm}$ in length were

Table 1. Minnesota and North Dakota counties where small grain plant collections were made during 2003, 2004, and 2005 in commercial production fields for aster yellows phytoplasma and Barley yellow dwarf virus detection ${ }^{\mathrm{a}}$

\begin{tabular}{|c|c|c|c|c|c|c|c|}
\hline \multirow[b]{2}{*}{ County } & \multirow[b]{2}{*}{ State } & \multicolumn{2}{|c|}{2003} & \multicolumn{2}{|c|}{2004} & \multicolumn{2}{|c|}{2005} \\
\hline & & Area (ha) & Fields & Area (ha) & Field & Area (ha) & Fields \\
\hline Becker & MN & 23,107 & 7 & 21,853 & 11 & 26,466 & 9 \\
\hline Big Stone & MN & 13,355 & 7 & 12,262 & 8 & 13,152 & 5 \\
\hline Clay & MN & 65,074 & 9 & 56,697 & 17 & 59,246 & 23 \\
\hline Clearwater & MN & 2,590 & 2 & 1,619 & 1 & 2,226 & 9 \\
\hline Douglas & $\mathrm{MN}$ & 7,406 & 5 & 6,556 & 0 & 7,689 & 6 \\
\hline Grant & MN & 17,442 & 10 & 14,973 & 19 & 14,043 & 3 \\
\hline Kandiyohi & $\mathrm{MN}$ & 1,943 & 0 & 2,145 & 0 & 2,388 & 2 \\
\hline Kittson & MN & 73,491 & 23 & 59,610 & 25 & 45,649 & 23 \\
\hline Mahnomen & MN & 13,759 & 6 & 10,320 & 8 & 13,638 & 10 \\
\hline Marshall & MN & 104,328 & 37 & 90,892 & 48 & 88,586 & 30 \\
\hline Norman & $\mathrm{MN}$ & 65,842 & 8 & 57,506 & 26 & 67,421 & 19 \\
\hline Otter Tail & MN & 25,698 & 5 & 23,350 & 13 & 27,438 & 4 \\
\hline Pembina & ND & 103,802 & 2 & 92,430 & 0 & 89,759 & 0 \\
\hline Pennington & $\mathrm{MN}$ & 29,825 & 16 & 27,802 & 22 & 28,490 & 18 \\
\hline Polk & MN & 124,643 & 45 & 133,717 & 61 & 124,765 & 52 \\
\hline Pope & $\mathrm{MN}$ & 3,723 & 4 & 4,006 & 0 & 4,290 & 5 \\
\hline Red Lake & $\mathrm{MN}$ & 22,460 & 23 & 21,367 & 29 & 23,553 & 19 \\
\hline Roseau & $\mathrm{MN}$ & 62,119 & 32 & 33,548 & 29 & 39,740 & 25 \\
\hline Stevens & $\mathrm{MN}$ & 8,296 & 8 & 7,568 & 8 & 8,134 & 2 \\
\hline Swift & $\mathrm{MN}$ & 3,278 & 0 & 4,249 & 0 & 6,475 & 5 \\
\hline Traverse & $\mathrm{MN}$ & 17,442 & 8 & 15,459 & 8 & 14,609 & 3 \\
\hline Walsh & ND & 100,241 & 2 & 97,005 & 0 & 105,825 & 2 \\
\hline Wilkin & $\mathrm{MN}$ & 55,644 & 12 & 53,014 & 17 & 54,552 & 4 \\
\hline Total & $\ldots$ & 999,372 & 271 & 890,723 & 350 & 918,517 & 278 \\
\hline
\end{tabular}

${ }^{\mathrm{a}}$ Area $=$ United States Department of Agriculture National Agricultural Statistics Service county estimates on area harvested for all wheat classes (1-3) and Fields = number of fields surveyed.

excised from upper and lower green leaves. All selected tissues were combined and ground in liquid nitrogen using a mortar and pestle. Total DNA extractions were done using DNeasy Plant Mini Kits (Qiagen, Valencia, CA) with $100 \mathrm{mg}$ of ground plant tissue for each extraction, according to the manufacturer's instructions.

PCR assays. A nested polymerase chain reaction (PCR) assay was used with the universal $16 \mathrm{~S}$ rDNA phytoplasma primer pair R16F2/R2 (Integrated DNA Technologies, Coralville, IA) (24). The first amplification consisted of $2.5 \mu \mathrm{l}$ of $10 \times$ PCR buffer (Fisher Scientific, Waltham, MA), $2.5 \mu \mathrm{l}$ of $2 \mathrm{mM}$ dNTPs, $1.5 \mu \mathrm{l}$ of 25 $\mathrm{mM} \mathrm{MgCl}, 2.5 \mu \mathrm{l}$ of $5 \mathrm{mM}$ primer solution, $14.75 \mu \mathrm{l}$ of sterile distilled water, 0.25 $\mu \mathrm{l}(25 \mathrm{U})$ of $T a q$ polymerase (Fisher Scientific), and $1 \mu \mathrm{l}$ of DNA extract, for a total volume of $25 \mu \mathrm{l}$. Negative control samples contained $1 \mu \mathrm{l}$ of sterile distilled water instead of DNA extract. Amplification was conducted (MJ Research PTC0200, Waltham, MA) with an initial denaturation cycle at $94^{\circ} \mathrm{C}$ for $2 \mathrm{~min}$ and 35 cycles at $94^{\circ} \mathrm{C}$ for $1 \mathrm{~min}, 50^{\circ} \mathrm{C}$ for $2 \mathrm{~min}$, and $72^{\circ} \mathrm{C}$ for $3 \mathrm{~min}$, followed by a final segment at $72^{\circ} \mathrm{C}$ for $10 \mathrm{~min}$. The second amplification was conducted with the same mixture as above, except $1 \mu$ of the products from the first amplification was used as the DNA template and an AYp group-specific rRNA primer pair R16(I)F1/R1 was used (23). Negative control samples contained $1 \mu \mathrm{l}$ of sterile distilled water. Amplification products from the second reaction were analyzed by electrophoresis in $1.0 \%$ agarose gels, stained with ethidium bromide, and visualized using UV light. The assay was used to detect AYp from field plants collected during 2003, 2004, and 2005.

In-field AYp pattern distribution was determined using a quantitative (q)PCR assay. Stored DNA extracts collected during 2004 and 2005 were analyzed if a sample from at least one transect location point per field previously had resulted in a positive AYp detection using the nested PCR assay. Samples were selected based on area and date that plants were collected. This was done to ensure representation of diverse growing environments and crop growth stages. In all, 75 and 51 tissue samples were retested from the 2004 and 2005 surveys, respectively, representing transect point locations 1 (nearest field edge), 3 (midpoint location on transect line), and 5 (point location furthest from the field edge). Primers for qPCR (5'-AACCCTCACCAGGTCTTGACA-3' and 5'-CACGAGCTGACGACAACCAT$\left.3^{\prime}\right)$ were designed using Primer Express Software (Applied Biosystems, Foster City, CA) and were selected within the sequence of the target gene amplicon $(1,100 \mathrm{bp})$ for the AYp group-specific rRNA PCR assay (23). The qPCR amplicon was designed to be $95 \mathrm{bp}$ (from base 
pair 765 to 860 of the 1,100-bp amplicon). qPCR assays were conducted using SYBR Green Supermix with ROX (Bio-Rad Laboratories, Inc., Hercules, CA), $1 \mu$ of DNA, and $50 \mathrm{nM}$ each primer in a $25-\mu \mathrm{l}$ reaction. Detection of AYp was conducted using the ABI Prism 7000 Sequence Detection System (Applied Biosystems). Reactions were incubated at $50^{\circ} \mathrm{C}$ for 2 min and $95^{\circ} \mathrm{C}$ for $3 \mathrm{~min}$, followed by 40 cycles of $15 \mathrm{~s}$ at $95^{\circ} \mathrm{C}$ and $1 \mathrm{~min}$ at $60^{\circ} \mathrm{C}$. Melting curve analysis was conducted using Applied Biosystems, Inc. software. Standard curves were constructed using dilutions of gel-purified PCR amplicon (1,100 bp) generated by PCR using the primers R16(1)F1/R1. Copy number for the target gene was determined based on DNA concentration of the gel-purified PCR amplicon. A dilution series of standard DNA was included to generate a standard curve for each experimental plate. Cycle threshold $(\mathrm{Ct})$ values for PCR standards were not affected when the standards were measured in a background of up to 80 ng of wheat DNA. Each sample was analyzed in triplicate. The amount of AYp DNA in each sample was quantified by comparing the average $\mathrm{Ct}$ values for wheat samples with $\mathrm{Ct}$ values on the standard curve.

Serological assays. Plant samples collected during 2003, 2004, and 2005 were tested in duplicate for the presence of PAV and RPV strains of BYDV. Approximately $0.3 \mathrm{~g}$ of leaf tissue from each sample was placed into a small mesh sample bag and macerated using a hand-held roller press (Agdia, Inc., Elkhart, IN). The resulting plant sap was tested for the presence of the PAV and RPV serotypes using doubleantibody sandwich enzyme-linked immunosorbent assays following the manufacturer's instructions (Agdia, Inc.). Serotypepositive and extraction-buffer-negative controls were tested in duplicate on each plate. Additional plant-derived controls were not used. A plant sample was considered positive if the absorbance reading (405 nm) of its duplicated test mean was greater than three times the absorbance of the negative control mean.

\section{RESULTS}

Regional distribution of AYp. During 2003, plants were collected from 251 wheat, 18 barley, and 2 oat (Avena sativa L.) fields over 40 survey days. Of the 271 fields surveyed, AYp was detected in $49 \%$ (present in 133 fields). AYp was detected for the first time from wheat and oat plants at the standardized growth development scale of Feekes growth stage (FGS) 1 that were collected 3 June (Fig. 1; 21). The phytoplasma was not detected in plant tissues from fields surveyed on 9 or 14 June, but was identified from $100 \%$ of fields surveyed on 3 June, 18 and 31 July, and 1 August. On 20 June, when the greatest number of fields was surveyed during a single day, AYp was detected from $36 \%$ of fields surveyed.

AYp was identified in each crop species and at all plant growth stages collected. In 2003, the pathogen was detected from plants collected at 7 of 10 fields in FGS 1, 17 of 34 fields in FGS 2 to 7 (tillering or jointing), 18 of 45 fields in FGS 8 to 10 (flag leaf emergence and unfolding), and 91 of 183 fields in FGS 10.1 to 16.0 (first awns emerging to kernel maturity; Fig. 2). Phytoplasma was detected from $48 \%$ of wheat fields surveyed (present in 120 of 252 ), $61 \%$ of barley fields surveyed (pres-
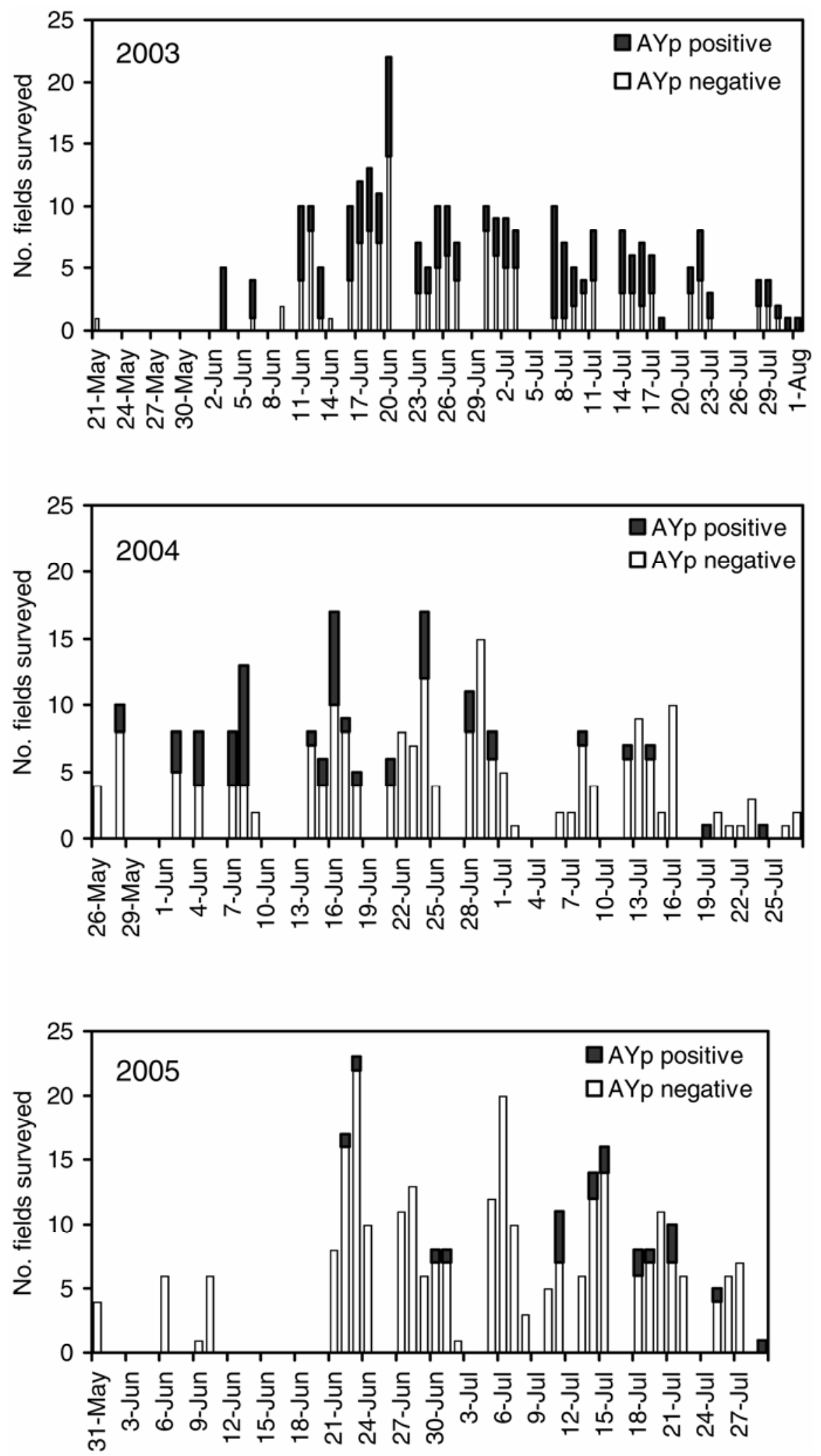

Fig. 1. Number of arbitrarily selected commercial small grains fields in Minnesota and North Dakota from which plants were collected during 2003, 2004, and 2005. Aster yellows phytoplasma (AYp) was detected (positive) or not detected (negative) using nested polymerase chain reaction. 

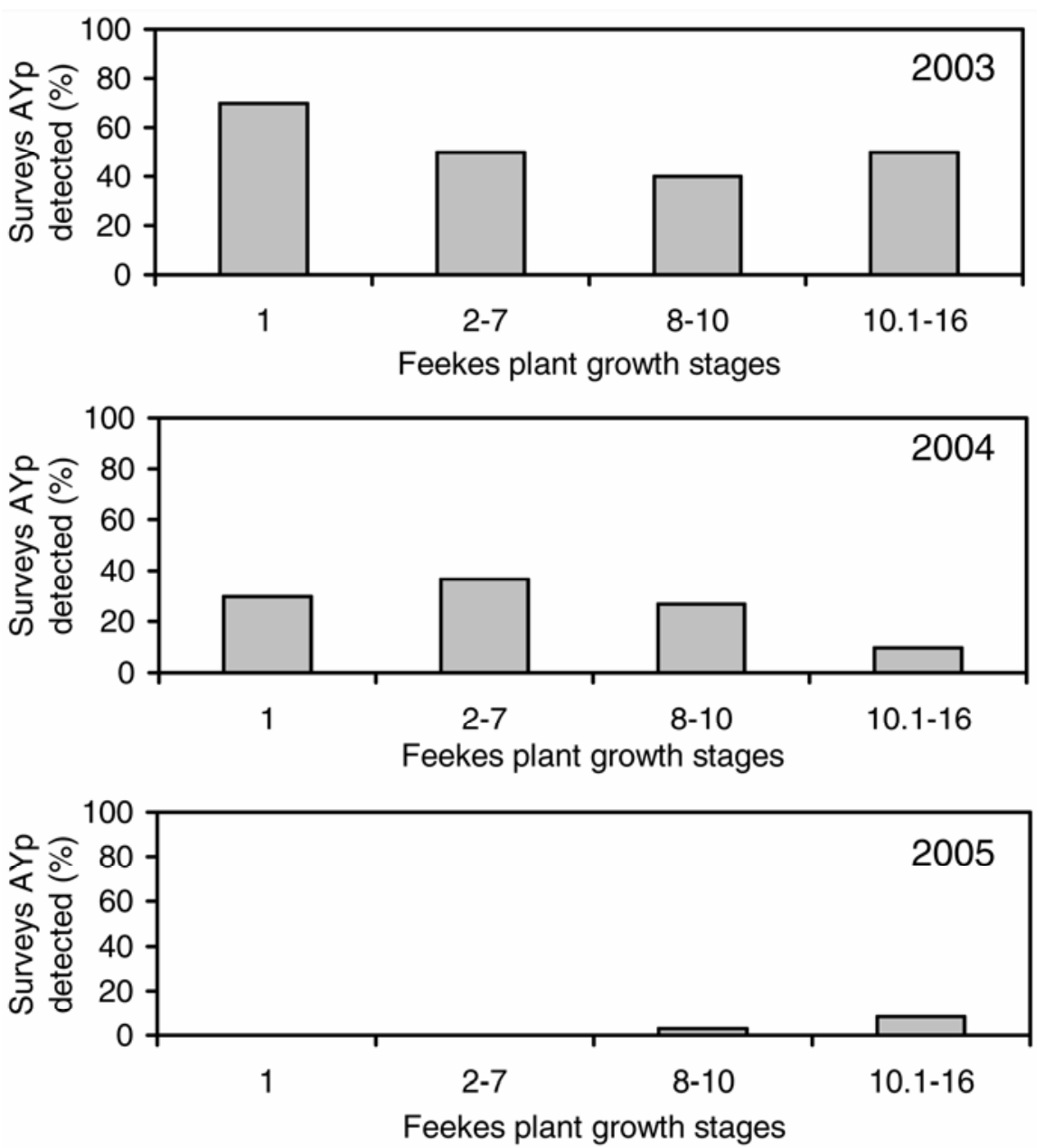

Fig. 2. Percent positive detection of aster yellows phytoplasma (AYp) from small grain plants at different Feekes growth stages (FGS) from 2003 to 2005. Plants were collected from commercial production fields in Minnesota and North Dakota. Plant growth stages were grouped as FGS 1 (three to four leaves unfolded), FGS 2 to 7 (tillering or jointing), FGS 8 to 10 (flag leaf emergence and unfolding), and FGS 10.1 to 16.0 (first awns emerging to kernel maturity).

Table 2. Percent commercial fields surveyed where aster yellows phytoplasma (AYp) was detected in plants collected from Minnesota and North Dakota during 2003, 2004, and 2005

\begin{tabular}{|c|c|c|c|c|}
\hline \multirow[b]{2}{*}{ County } & \multirow[b]{2}{*}{ State } & \multicolumn{3}{|c|}{ Fields with AYp-infected plants $(\%)^{a}$} \\
\hline & & 2003 & 2004 & 2005 \\
\hline Becker & MN & 29 & 7 & 11 \\
\hline Big Stone & MN & 29 & 10 & 20 \\
\hline Clay & MN & 56 & 9 & 4 \\
\hline Clearwater & MN & 100 & 0 & 11 \\
\hline Douglas & MN & 60 & - & 17 \\
\hline Grant & MN & 40 & 8 & 33 \\
\hline Kandiyohi & $\mathrm{MN}$ & - & - & 0 \\
\hline Kittson & MN & 39 & 5 & 9 \\
\hline Mahnomen & MN & 50 & 2 & 0 \\
\hline Marshall & MN & 46 & 15 & 3 \\
\hline Norman & MN & 25 & 20 & 11 \\
\hline Otter Tail & MN & 60 & 0 & 0 \\
\hline Pembina & ND & 100 & - & - \\
\hline Pennington & MN & 56 & 4 & 6 \\
\hline Polk & MN & 38 & 21 & 2 \\
\hline Pope & $\mathrm{MN}$ & 100 & - & 20 \\
\hline Red Lake & MN & 61 & 7 & 11 \\
\hline Roseau & MN & 59 & 7 & 4 \\
\hline Stevens & $\mathrm{MN}$ & 50 & 2 & 0 \\
\hline Swift & MN & - & - & 0 \\
\hline Traverse & MN & 25 & 0 & 0 \\
\hline Walsh & ND & 100 & - & 0 \\
\hline Wilkin & MN & 67 & 6 & 25 \\
\hline
\end{tabular}

a Symbol - = no fields within county surveyed. ent in 11 of 18), and $100 \%$ of oat fields surveyed (present in 2 of 2). AY-infected plants were collected from wheat fields during FGS 1 to 16 , barley fields during FGS 2 to 16, and oat fields during FGS 1.

In 2003, fields in which AYp was detected were widely scattered. Moran's index (-0.006) indicated that AYp-infected fields were distributed evenly within the surveyed area. The pathogen was detected from all 21 counties surveyed (Table 2). Norman and Traverse Counties had the fewest AYp detections (25\%), whereas AYp was identified from plants in $100 \%$ of surveyed fields in Clearwater and Pope Counties in Minnesota, as well as Pembina and Walsh Counties in North Dakota (Fig. $3)$.

During 2004, plants were collected from 341 wheat, 8 barley, and 1 oat fields over 39 survey days. Of the 350 fields surveyed, AYp was detected from plants in $15 \%$ of fields (present in 51 fields). AYp was detected for the first time from wheat plants collected 28 May (Fig. 1) at FGS 1. The phytoplasma was detected more often from fields surveyed earlier in the growing season rather than later. AY-infected plants were collected during $50 \%$ of survey days in May (1 of 2), $72 \%$ of days in June (13 of 18), and $26 \%$ of days in July (5 of 19).

AYp was detected from plants collected at 8 of 27 fields in FGS 1, 21 of 89 fields in FGS 2 to 7, 10 of 52 fields in FGS 8 to 10, and 12 of 182 fields in FGS 10.1 to 16 (Fig. 2). AYp was detected in plants from $14 \%$ of the wheat fields surveyed (present in 49 of 341) and $25 \%$ of the barley fields surveyed (present in 2 of 8 ). It was not detected in the oat field surveyed. Wheat and barley plants were collected during FGS 1 to 16 and oat plants during FGS 2 to 7 .

As in the previous year, fields in which AYp was detected during 2004 were widely scattered. Moran's index $(-0.013)$ indicated that AYp-infected fields were distributed evenly within the surveyed area. The pathogen was detected in plants from all but three counties surveyed (Table 2 ). The pathogen was not detected in Clearwater, Otter Tail, and Traverse Counties. Polk County had the highest percentage of fields $(21 \%)$ in which AYp was detected (Fig. 3)

During 2005, plants were collected from 265 wheat, 12 barley, and 1 oat fields over 32 survey days. Of the 278 fields, AYp was detected from plants collected from $6 \%$ (present in 20 fields) of those surveyed. AYp was detected for the first time from wheat plants collected on 22 June (Fig. 1) at FGS 8 to 10 . The pathogen was detected from plants collected during $27 \%$ of survey days in June (present in 3 of 11) and $45 \%$ of survey days in July (present in 9 of 20).

During 2005, the pathogen was detected later in the growing season and at later plant growth stages than during the previ- 

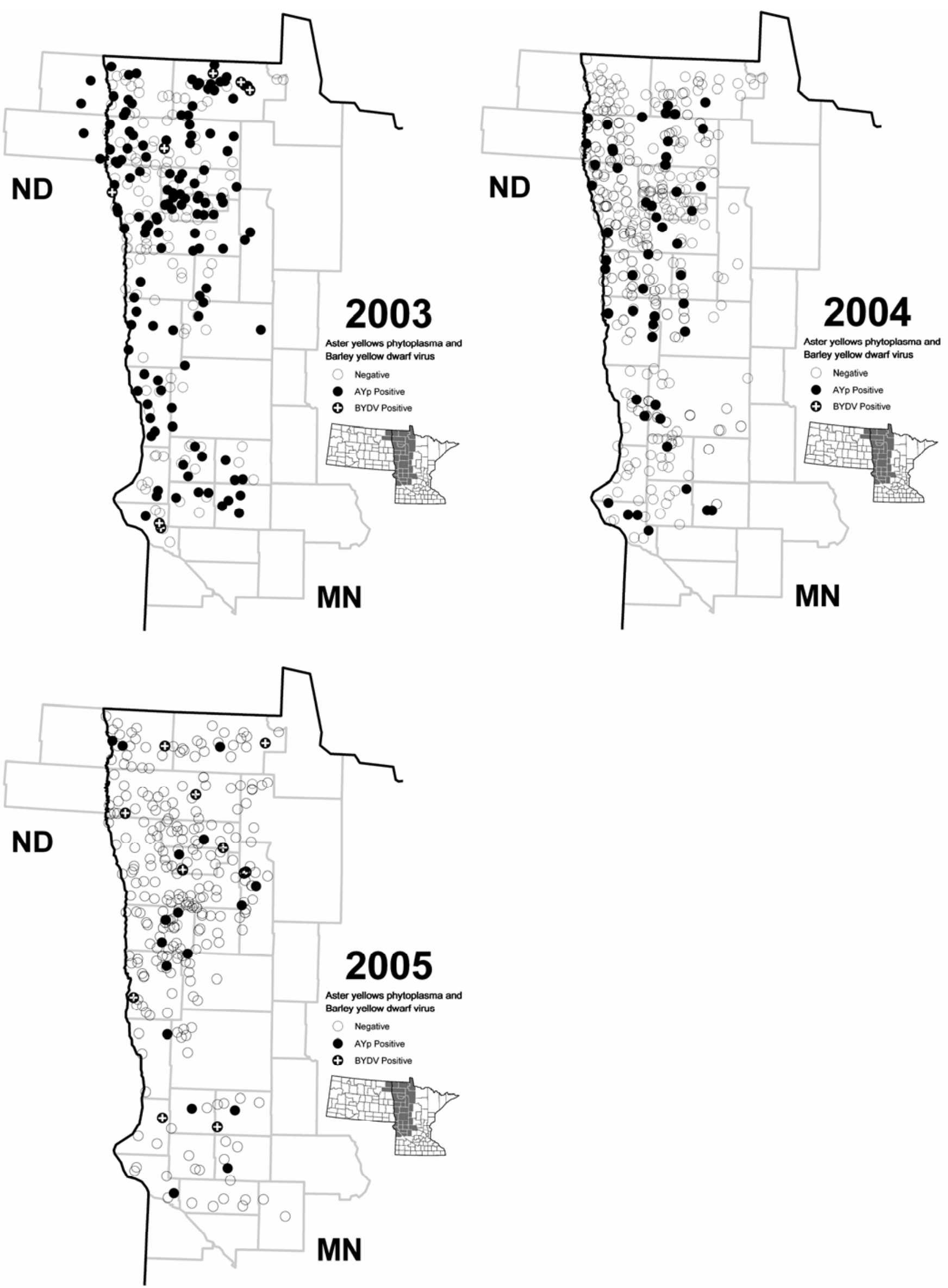

Fig. 3. Geographical distribution of survey results for detecting aster yellows phytoplasma (AYp) and Barley yellow dwarf virus (BYDV) in plants from commercial small grain production fields in the Red River Valley of Minnesota and North Dakota during 2003, 2004, and 2005. 
ous 2 years. AYp was detected from plants collected at 1 of 34 fields in FGS 8 to 10 and 17 of 226 fields in FGS 10.1 to 16 (Fig. 2). Phytoplasma was detected from plants in $7 \%$ of wheat fields surveyed (present in 18 of 268). AYp was not detected in oat or barley plants. Plant collections were made in the wheat fields during FGS 1 to 16, in the barley fields during FGS 2 to 10, and in the oat field during FGS 1.

In 2005, fields in which AYp was detected were scattered. Moran's index $(-0.078)$ indicated that AYp-infected fields were distributed evenly across the surveyed area. The pathogen was detected in plants from 16 of 23 counties surveyed (Table 2). It was not detected in Kandiyohi, Mahnomen, Otter Tail, Stevens, Swift, and Traverse Counties in Minnesota or Walsh County in North Dakota (Fig. 3). Grant County in Minnesota had the largest

Regional distribution of BYDV. Plant sap was tested from plants collected from each field (2003 and 2004) or each transect point (2004 and 2005) for the PAV and RPV serotypes of BYDV. During 2003, the PAV serotype was detected in plants from $2 \%$ of fields (present in 6 of 271), including 5 wheat and 1 barley. The RPV serotype was detected in plants from less than $1 \%$ of fields (present in 1 of 271), and was identified from infected wheat. Plants infected with BYDV were collected during June and July in FGS 7 to 16 . The PAV percent AYp detection, at 33\%.

serotype was detected from counties located in the west-central to northern Red River Valley of Minnesota in Big Stone, Polk, Kittson, and Roseau Counties (Fig. 3 ). The RPV serotype was detected from Marshall County, located in the northern Red River Valley. Detections of BYDV were widely scattered. Barley plants at FGS 8 to 10 collected from one field in Kittson County were infected with both the PAV serotype and AYp. During 2004, neither PAV nor RPV serotypes of BYDV were detected in collected plant samples.

During 2005, slightly more fields were infected with BYDV compared with the previous 2 years. The PAV serotype was detected in plants from less than $1 \%$ of fields (present in 1 of 281) and the RPV serotype was detected in plants from $4 \%$ of fields (present in 12 of 281). Infected plants were collected during June and July in FGS 7 to 16. The PAV serotype was identified from Kittson County located in the northernmost Red River Valley of Minnesota, and the RPV serotype was identified in 9 of the 23 counties located throughout the Red River Valley in Clay, Clearwater, Douglas, Kittson, Marshall, Pennington, Red Lake, Roseau, and Traverse Counties (Fig. 3). Detections of BYDV were widely scattered. No double infections (BYDV and AYp) were detected.

Field distribution of AYp. A qPCR assay was used to quantify AYp from a subset of plant samples that previously were
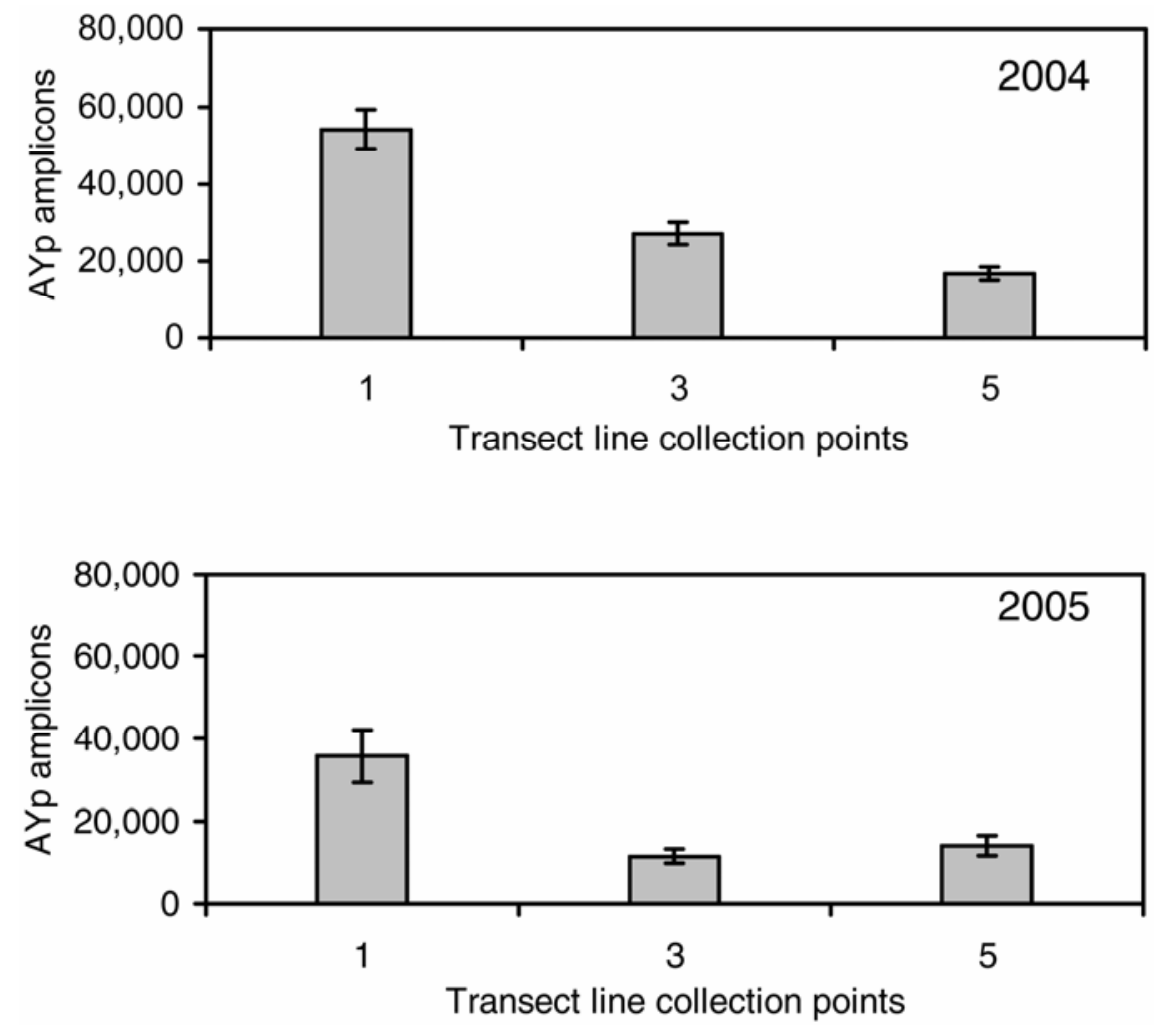

Fig. 4. Aster yellows phytoplasma (AYp) amplicon count means resulting from quantitative real-time polymerase chain reaction assays of wheat plants collected during 2004 and 2005 from commercial production fields in the Minnesota Red River Valley. Plants were collected at five transect location points, with point 1 nearest the field edge, point 3 at midpoint, and point 5 furthest from the field edge. tested with the nested PCR assay. A standard curve was constructed by plotting average $\mathrm{Ct}$ values for 10 -fold dilutions of the conventional PCR amplicon versus the logarithm of the starting copy number for each dilution of PCR amplicon. The standard curve showed a linear relationship between $\mathrm{Ct}$ values and the logarithm of the starting template copy number. The assay was quantitative and reproducible over a wide range of concentrations, greater than five orders of magnitude. The assay detected as few as 100 copies of the AYp target $16 \mathrm{~S}$ ribosomal DNA (rDNA). For all experiments, the linear coefficient of the standard curve was $R^{2}=0.97$ to 0.99 and the slope of the curve was in a range corresponding to 90 to $100 \%$ efficiency for PCR.

From samples collected in 2004, AYp was detected from $48 \%$ (present in 12 of 25), $36 \%$ (present in 9 of 25), and $40 \%$ (present in 10 of 25) of plant collections made at transect location points 1,3 , and 5 , respectively. Samples of DNA originating from a wheat field in Wilkin County and collected on 16 June resulted in the highest AYp amplicon copy numbers of 5.5 $\times 10^{5}$ and $3.1 \times 10^{5}$ for transect location points 1 and 3 , respectively. The largest amplicon copy number for transect location point 5 was $1.9 \times 10^{5}$ from a wheat plant sample collected in Grant County on 30 June. Samples with the lowest AYp amplicon copy numbers, 114 and 259 , were collected from a Grant County wheat field on 17 June at the 1 and 5 transect location points, respectively. Transect location point 3 , with the lowest amplicon copy number of $2.9 \times 10^{3}$, was collected from a separate Grant County wheat field on 30 June. The mean amplicon copy number for transect location point 1 was nearly two times larger than location point 3 (point $1,5.4 \times 10^{5}$ and point $3,2.7 \times$ $10^{5}$ ). Means decreased as the distance increased from field edges (point 5, $1.7 \times$ $10^{5}$ copies; Fig. 4 ).

From the 2005 samples, AYp was detected from $29 \%$ (present in 5 of 17), 35\% (present in 6 of 17), and 29\% (present in 5 of 17) of collections made at transect location points 1,3 , and 5 , respectively. Samples from a wheat field in Douglas County collected on 14 July resulted in the highest amplicon copy numbers of $4.3 \times 10^{5}, 1.2 \times$ $10^{5}$, and $1.7 \times 10^{5}$ for transect points 1,3 , and 5, respectively. Samples with the lowest amplicon copy numbers at the 1 and 5 transect location points, 534 and 2,907, respectively, were collected from a Roseau County wheat field on 15 July. Transect location point 3 sample with the lowest copy number was collected from Kittson County on 14 July. The mean amplicon copy number at transect location points showed a field pattern similar to the 2004 samples. The mean transect location point 1 amplicon copy number was 2.5 times greater than the next largest mean at loca- 
tion point 5 (point $1,3.6 \times 10^{4}$ and point 5 , $1.4 \times 10^{4}$ ) and was three times larger than the mean of location point $3\left(1.2 \times 10^{4}\right.$; Fig. 4).

\section{DISCUSSION}

This research showed that AYp was more prevalent in the Red River Valley during 2003, 2004, and 2005 than BYDV. Casual diagnoses of BYD or AY based solely on plant symptoms are questionable, at best. Diseased plants have nondescript blotchy to linear chlorosis on foliage that are similar to symptoms caused by environmental stresses or natural plant senescence. Still other infected plants may have more subtle symptoms or no symptoms at all.

Research on phytoplasmas has lagged behind that of culturable pathogens or viruses. In general, nested PCR assays that require two rounds of DNA amplification have been used to classify and detect phytoplasmas. A qPCR assay was needed to detect and quantitatively assess phytoplasma from host plant tissues. The qPCR assay described here provides a more rapid and quantitative AYp disease diagnostic tool than nested PCR.

Previously, AYp was shown to have two rDNA operons (36). The qPCR assay reproducibly detected 100 copies of the amplicon. Thus, theoretically, the assay detected as few as 50 individual phytoplasmas. However, in the absence of a purified sample of AYp, the efficiency of DNA extraction and phytoplasma detection could not be tested. A comparison of results of qPCR and nested PCR reactions with the same DNA samples indicated that the qPCR assay has sensitivity similar to that of the nested PCR assay.

Wheat plants with AYp were detected each year of the study; infected barley plants were identified in 2 of 3 years (2003 and 2004) and infected oat plants were detected 1 of 3 years (2003). The high incidence of AYp in crop species may be due to feeding preferences of aster leafhoppers. Small grain crops are a preferred food source for the aster leafhopper $(28,35,40)$. However, reports are conflicting as to which small grain species is most preferred. Using field survey data, leafhoppers appeared to prefer barley plants over wheat plants (40), whereas laboratory cage studies indicated that leafhoppers preferred wheat plants over oat and barley plants (28). Westdal and Richardson (41) concluded that oat plants were a preferred food crop, and promote increased leafhopper populations. Crop species infection by AYp in the Red River Valley may be more dependent on prevalence of land area of specific crops rather than vector feeding preference. From 2003 to 2005, oat and barley crops combined were grown on less than $15 \%$ of the number of hectares that wheat was grown on $(530,000$ to 716,000 ha; 2). Wheat is concentrated within the
Red River Valley area, providing an abundance of fields with a preferred crop for migrating and locally emerging aster leafhopper populations.

Plant collections were initiated each growing season during late May. The earliest detection of AYp was made from plants collected during 2004, followed by 2003 and then 2005. During 2003 and 2004, the first AYp detection each growing season was made from plants collected during the second survey day. AYp-infected plants were more prevalent during 2003 than during 2004 or 2005.

During 2004, the weather was unseasonably cool. Growing degree days were reduced, resulting in abnormally tall plant heights, excessive vegetative growth, and lush plant canopies. Initial AYp detection during 2004 was similar to 2003 until late June, when fewer AYp-infected plants were identified. Small grain plants are typically at or near FGS 9 to 10 about this time, depending on field location. It is likely that detection of AYp was less efficient as plant biomass increased. Populations of phytoplasma are concentrated near sieve tubes in the phloem transport system rather than being evenly distributed throughout the plant $(12,17)$. Successful detection of the organism becomes increasingly difficult as plant biomass increases and phloem transport cells are extended. During 2004, it is possible that difficulties in AYp detection during the later growing season resulted in reduced detection, or false negatives, because it is unlikely that a curative event occurred near 1 July.

During 2005, AYp was detected later in the growing season than in previous years. The first detection was made during late June and sporadic diagnoses continued throughout the remainder of the season. The disease development pattern likely resulted from either the late arrival of infested leafhopper vectors migrating into the agroecosystem from more southerly locations, or from locally emerging leafhopper populations feeding on AYpinfested perennial host plants and then becoming infective following an insect incubation period. A minimum incubation period in noninfected, locally emerging leafhoppers can range from 11 to 29 days before phytoplasma are transmitted in sufficient quantities to cause disease in plants (26). Migrating leafhoppers are known to leave crops in southern states when crop conditions deteriorate and warm air flows support flights to northern areas $(8,30)$. Timings of flights and density of insect populations at destination locations depend on crop conditions in the southern United States and temperature and direction of air plume trajectories $(8,30)$. These can be variable from year to year, resulting in unpredictable leafhopper population migrations. Visual comparisons using mapping software were made of field locations where infected plants were detected based on plant growth stage and calendar date. Spatial patterns of AYp detection were not apparent within or between years.

The number of fields where plants were infected with BYDV was small and widely scattered each year it was detected. In all, $3 \%$ of fields had plants that were detected with BYDV during 2003 (present in 7 of 271); during 2004, BYDV was not detected (present in 0 of 350). During 2005, $5 \%$ of fields were infested with BYDV (present in 13 of 281) compared with 6\% of fields where AYp was detected (present in 18 of 281). Both diseases were at very low incidences that year.

Previous research indicates that aster leafhopper populations are evenly distributed within wheat fields and migration from borders is negligible (9). Our data indicate an in-field spatial trend of plant infection. AYp amplicon copy numbers were 3-fold and 2.5-fold greater in 2004 and 2005, respectively, from plants sampled near field edges compared with plants sampled toward the field center. Higher DNA copy numbers are indicative of greater populations of AYp in the host, which could occur from an extended period of active multiplication, or with passive accumulation resulting from feeding activities of infected leafhoppers. Detection of phytoplasma using PCR assays is expected to be difficult and unreliable with passive accumulation because of its inherently localized nature. Reliable detection of phytoplasma from an infected plant relies on systematic spread of the pathogen in the host. Active multiplication and an increasing interval following infection increase the likelihood that the pathogen will be detected using PCR assays. This type of spatial pattern suggests that vectors migrate into fields from perimeter areas, such as grass ditches and field margins. Madden et al. (25) found little spatial structure in the distribution of AY in lettuce fields, whereas subsequent research in the crop has indicated an aggregated distribution (7). Authors of the latter study speculated this was due to vector behavioral differences. Female aster leafhoppers acquire and transmit the pathogen at greater frequencies than males (6). In addition, females are more sedentary than males and are less likely to move from plant to plant after a suitable host is located $(6,15)$. If the most efficient vectors of AYp are arriving at field edges from ditches and are not motivated to move further into the field, the distribution we report would be biologically and behaviorally sound. This type of field pattern information may be useful for developing future AY disease management strategies for small grain crops.

Diagnoses of BYD in small grain crops are questionable in the absence of laboratory tests in the Upper Midwest. Results from this research illustrate the need for 
heightened awareness of AY, a common but largely undetected disease in small grain crops.

\section{ACKNOWLEDGMENTS}

We thank the Minnesota Department of Agriculture commercial field pest surveyors for plant collections; J. Machado, University of Minnesota graduate research assistant, and numerous undergraduate students for assistance with the field survey and tissue processing; the Minnesota Wheat Research and Promotion Council, Minnesota Agricultural Research and Utilization Institute Pesticide Reduction Options Program, and the University of Minnesota Graduate School Grant-in-Aid for financial support; and M. Zutz, Minnesota Barley Research and Promotion Council, for his funding sponsorship.

\section{LITERATURE CITED}

1. Anonymous. 2005. Crop County Estimates. Pages 34-58 in: 2005 Minnesota Agricultural Statistics. U. S. Dep. Agric., St. Paul, MN

2. Anonymous. 2006. Crop County Estimates. Pages 22-46 in: 2006 Minnesota Agricultural Statistics. U. S. Dep. Agric., St. Paul, MN

3. Anonymous. 2007. http://www.nass.usda.gov/ Statistics_by_State/North_Dakota/

4. Banttari, E. E. 1965. Occurrence of aster yellows in barley in the field and its comparison with barley yellow dwarf. Phytopathology 55:838-843.

5. Banttari, E. E. 1990. Aster yellows. Pages 8-9 in: Compendium of Barley Diseases, 2nd ed. D. E. Mathre, ed. American Phytopathological Society Press, St. Paul, MN.

6. Beanland L., Hoy, C. W., Miller, S. A., and Nault, L. R. 1999. Leafhopper (Homoptera: Cicadellidae) transmission of aster yellows phytoplasma does gender matter? Environ. Entomol. 28:1101-1106.

7. Beanland, L., Madden, L. V., Hoy, C. W., Miller, S. A., and Nault, N. A. 2005. Temporal distribution of aster leafhopper sex ratios and spatial patterns of aster yellows phytoplasma disease in lettuce. Ann. Entomol. Soc. Am. 98(6):756-762.

8. Chapman, R. K. 1973. Integrated control of aster yellows. Proc. North Cent. Branch Entomol. Soc. Am. 28:71-92.

9. Chiykowski, L. N., and Chapman, R. K. 1956. Long distance migration of the six-spotted leafhopper in relation to aster yellows in Wisconsin. Proc. North Cent. Branch Entomol. Soc. Am. 11:53.

10. Christensen, N. M., Axelsen, K. B., Nicolaisen, M., and Schulz, A. 2005. Phytoplasmas and their interactions with hosts. Trends Plant Sci. 10:526-535

11. Davis, R. E., and Sinclair W. A. 1998. Phytoplasma identity and disease etiology. Phytopathology 88:1372-1376.

12. Gundersen, D. E., and Lee, I.-M. 1996. Ultrasensitive detection of phytoplasmas by nestedPCR assays using two universal primer pairs.
Phytopathol. Mediterr. 35:144-151.

13. Gundersen, D. E., Lee, I.-M., Rehner, S. A., Davis, R. E., and Kingsbury, D. T. 1994. Phylogeny of mycoplasmalike organisms (Phytoplasmas): a basis for their classification. J. Bacteriol. 176:5244-5254.

14. Hoy, C. W., Heady, S. E., and Koch, T. A. 1992. Species composition, phenology, and possible origins of leafhoppers (Cicadellidae) in Ohio vegetable crops. J. Econ. Entomol. 85:2336-2343.

15. Hoy, C. W., Zhou, X., Nault, L. R., Miller, S. A., and Stryrer, J. 1999. Host plant, phytoplasma, and reproductive status effects on flight behavior of aster leafhopper (Homoptera: Cicadellidae). Ann. Entomol. Soc. Am. 92:523-528.

16. Ishiie, T., Doi, Y., Yora, K., and Asuyama, H. 1967. Suppressive effects of antibiotics of tetracycline group on symptom development of mulberry dwarf diseases. Ann. Phytopathol. Soc. Jpn. 33:267-275

17. Kirkpatrick, B. C. 1984. Strategies for characterizing plant pathogenic mycoplasma-like organisms and their effects on plants. Pages 241293 in: Plant-Microbe Interactions Molecular and Genetic Perspectives, Vol. 3. T. Kosuge and E. W. Nester, eds. McGraw-Hill Publ., New York.

18. Kirkpatrick, B. C., and Smart, C. D. 1995. Phytoplasmas: Can phylogeny provide the means to understand pathogenicity? Pages 187-212 in: Advances in Botanical Research, Vol. 21. J. H. Andrews and I. C. Tommerup, eds. Academic Press, New York.

19. Kunkel, L. O. 1937. Effect of heat on ability of Cicadula sexnotato (Fall.) to transmit aster yellows. Am. J. Bot. 24:316-327.

20. Kunkel, L. O. 1941. Heat cure of aster yellows in periwinkles. Am. J. Bot. 28:761-769.

21. Large, E. C. 1954. Growth stages in cereals: Illustration of the Feekes scale. Plant Pathol. 3:128-129.

22. Lee, I.-M., Davis, R. E., and GundersenRindal, D. E. 2000. Phytoplasma: Phytopathogenic mollicutes. Annu. Rev. Microbiol. 54:221-255.

23. Lee, I.-M., Gunderson, E. E., Hammond, R. W., and Davis, R. E. 1994. Use of mycoplasmalike organism (MLO) group-specific oligonucleotide primers for nested-PCR assays to detect mixed-MLO infections in a single host plant. Phytopathology 84:559-566.

24. Lee, I.-M., Hammond, R. W., Davis, R. E., and Gundersen, D. E. 1993. Universal amplification and analysis of pathogen 16S rDNA for classification and identification of mycoplasmalike organisms. Phytopathology 83:834842.

25. Madden, L. V., Nault, L. R., Murral, D. J., and Apelt, M. R. 1995. Spatial pattern analysis of the incidence of aster yellows disease in lettuce. Res. Population Ecol. 37:279-289.

26. Maramorosch, K. 1953. Incubation period of aster-yellows virus. Am. J. Bot. 40:799-809.

27. Maramorosch, K. Granados, R. R., and Hi- rumi, H. 1970. Mycoplasma diseases of plants and insects. Pages 135-193 in: Advances in Virus Research. K. M. Smith, M. A. Lauffer, and F. B. Bang, eds. Academic Press, New York.

28. McClanahan, R. J. 1962. Food preferences of the six-spotted leafhopper, Macrosteles fascifrons (Stål). Proc. Entomol. Soc. Ont. 93:9092.

29. McMullen, M. 2001. Small grain disease update. North Dakota State University Crop and Pest Report. http://www.ag.ndsu.nodak. edu/aginfo/entomology/ndsucpr/Years/2001/ June/21/ppath_21June01.htm\#SMALL.

30. Meade A. B., and Peterson, A. G. 1964. Origin of populations of the six-spotted leafhopper, Macrosteles fascifrons, in Anoka County, Minnesota. J. Econ. Entomol. 57:885-888.

31. Minnesota Department of Agriculture. 2001 Minnesota pest report annual summary. M. D. Abrahamson, ed. http://www.mda.state.mn.us/ plants/pestmanagement/pestreports.htm.

32. Moran, P. A. P. 1950. Notes on continuous stochastic phenomena. Biometrika 37:17-23.

33. Noetzel, E. M., Cutkomp, L. K., and Harein, P. K. 1983. Estimated annual losses due to insects in Minnesota 1981-1983. University of Minnesota AES, AG-BU-2541.

34. O'Rourke, P. K., Burkness, E. C., and Hutchison, W. D. 1998. Development and validation of a fixed-precision sequential sampling plan for aster leafhopper (Homoptera: Cicadellidae) in carrot. Environ. Entomol. 27:1463-1468.

35. Peterson, A. G. 1973. Host plant and aster leafhopper relationships. Proc. North Cent. Branch Entomol. Soc. Am. 28:66-70.

36. Schneider, B., and Seemüller, E. 1994. Presence of two sets of ribosomal genes in phytopathogenic mollicutes Appl. Environ. Microbiol. 60.3409-3412.

37. Schultz, G. A. 1973. Plant resistance to aster yellows. Proc. North Cent. Branch Entomol. Soc. Am. 28:93-99.

38. Timian, R. G., and Alm, K. R. 1977. Antibiotic treatment of barley infected with aster yellows. Plant Dis. Rep. 61:522-524.

39. Westdal, P. H. 1968. The experimental approach in assessing disease losses in cereals: Aster yellows in barley. Can. Plant Dis. Surv. 48:76.

40. Westdal, P. H., Barrett, C. F., and Richardson, H. P. 1960. The six-spotted leafhopper, Macrosteles fascifrons (Stål.) and aster yellows in Manitoba. Can. J. Plant Sci. 41:320-331.

41. Westdal, P. H., and Richardson, H. P. 1968. The susceptibility of cereals and wild oats to an isolate of the aster yellows pathogen. Can. J. Bot. 47:755-760

42. Whitcomb, R. F., and Black, L. M. 1982. Plant and arthropod mycoplasmas: a historical perspective. Pages 40-81 in: Plant and Insect Mycoplasma Techniques. M. J. Daniels and P. G. Markham, eds. Halsted Press, New York.

43. Windsor, I. M., and Black, L. M. 1973. Remission of symptoms of clover club leaf following treatment with penicillin. Phytopathology 63:44-46 